\title{
An Exploratory Study for Opening Accounting Undergraduate Program in Saudi Arabia: The Stakeholders' Perception \& Need Analysis
}

\author{
Dr. Humera Shahid \\ Assistant Professor, Department of Business Administration \\ Jubail University College, Saudi Arabia \\ Dr. Asha Alexander \\ Associate Professor, Department of Business Administration \\ Jubail University College, Saudi Arabia \\ Dr. Tayfour Abdalla Mohammed Abdalla \\ Assistant Professor, Department of Business Administration \\ Jubail University College, Saudi Arabia
}

\begin{abstract}
Purpose: Educational institutions are transforming their programs' learning outcomes from theory based to mixed based consisting of theory, practical and technology in order to equip graduates with skills that are highly demanded by industry due to digital transformation especially in professions like accounting and finance. This study aims to conduct a need analysis in order to get stakeholders' perception for opening of IT based undergraduate accounting program in the eastern province of the Kingdom of Saudi Arabia in order to provide IT skilled accounting professional to Industry. Design/methodology/approach: There is use of both qualitative and quantitative data in a manner that enables insight to be mutually illuminating. Principal Component Analysis (PCA) was carried out in order to group the 15 manifest variables into few latent variables. Factor analysis has reduced variables to two factors and analysis of variance was applied to test the main differences between groups. Findings: Findings have shown a favorable perception of the stakeholders for opening of undergraduate Accounting program focusing on knowledge, cognitive, interpersonal as well as technology based skills. Industry experts has shown a positive attitude about demand for students passing out from such degree. Originality/value: This study has provided an insight about the rising importance of accounting programs in developing country for researchers, educators and practitioners. This could be explored by further research to set up specific initiatives aimed at enhancing those aspects of the accounting program that are overshadowed or undermined in curriculum.
\end{abstract}

Keywords: Accounting Program, Need Analysis, Stakeholders, Perception, Undergraduate Studies

\section{INTRODUCTION}

Significant improvements in information technology have empowered the companies to computerize their organizational functions. This seems to be more effective especially in field of Accounting as it is an art of recording, classifying, and summarizing essential economic data of companies. The chances of errors in accounting process have reduced significantly due to computerization of accounting information systems. Hence accountants are required to gain the skills to use computerized systems Ghasemi et. al (2011). This process takes time in order to (1) firstly train the new employees on accounting information systems, (2) followed by 
training in latest accounting standards (IFRS) and (3) then continuous improvements (professional exams) to work at senior levels.

The kingdom of Saudi Arabia is the biggest economy in the Arabian Gulf with a gross domestic product (GDP) of 646 billion USD, a GDP per capita of 20,813 USD and a population of 31.4 million (Employment Outlook, April 2017). It owns approximately one-fifth of the world's proven oil reserves and its crude oil sector accounts for about 50 percent of GDP. Saudi Arabia has called for a number of steps to diversify its economy in order to both move away from dependence on oil and gas (Saudi Vision 2030). The core focus of 2030 vision is to reduce youth unemployment and increase overall Saudi nationals' participation in the workforce. The current high degree of state expenditure on long term development projects ensures robust growth in the non-oil sector, especially in new renewable energy. Recent reports suggest that job seekers with professional, technological and managerial skills will find that their skills remain in high demand for the foreseeable future so will the accounting positions. Often, these accounting positions are an integral part of corporate management and may be company Presidents and Chief Executive Officers, Chief Financial Officers, or Corporate Controllers. On the other hand many others prefer to work in accounting firms where they can offer assurance services, financial advising, tax planning, or a variety of consulting services to clients.

Saudi companies are also facing a fresh challenge from new accounting measures that could provide windfall gains for some but saddle others with higher commissions. In an attempt to bring the Saudi stock market into the global investing mainstream, the Capital Market Authority has told the nation's 175 listed companies to embrace International Financial Reporting Standards (IFRS). Most Saudi companies have used local accounting standards, known as SOCPA (Saudi Organization for Certified Public Accounting) for decades and a switch to IFRS demands subsequent revaluation.

In response to the demand and pressure presented by competitive and globalized economy and bring down the gap between training, research and business practice there is a growing demand to educate professionals and researchers in the area of Accounting. (The National, UAE, 2016).

The undergraduate Accounting major is a management program usually introduced under the college /School of Business. The college of Business offers unique fulltime majors such as Accounting, Business Administration, Business Analytics, Finance, Information System, Marketing and Supply Chain Management. Each major will expose students to learning environments that will equip them to sustain competitive advantage in today's management field. Every academic year, administrators frame diversification strategies for opening possible majors. This provides a wide range of educational choices for students within the campus. Generic statements that indicate the "need" for the proposed academic program are not satisfactory. The academic units are required to make available proof that includes market research addressing student demand, projected enrollment, assessment of workforce demand and competitive advantage for the university. Needs assessment survey helps to evaluate the opportunity to expand and launch new accounting major in the eastern province of Saudi Arabia. This helps to estimate the probability of meeting community needs, the needs of the new economy, the risk of low enrollment and non-duplication with other programs.

Accounting course is ordinarily instructed in all majors offered by College of Business, however a four-year accounting program which leads to the Bachelor of Science (B.S.) degree will assist students to build up a rich understanding of accounting rules, theories, concepts, critical thinking, application of accounting regulations, measures and laws to solve accounting 
problems. The students will be prepared to defend accounting decisions using appropriate terminology and demonstrate professional conduct to resolve ethical accounting dilemmas.

Extensive research relating to accounting has been conducted in Western countries such as the USA (Hunt et al., 2004; White and White, 2006), Canada (Diminik and Felton, 2006), UK (Friedman and Lyne, 1997, 2001), and Germany (Hoffjan, 2004). However, there is a dearth of literature relating to this in developing countries like Saudi Arabia. Looking into and investigating new research contexts within this framework therefore becomes more and more appealing. This paper explores stakeholders' perception as well as need analysis for opening accounting undergraduate programs in Saudi Arabia.

\section{REVIEW OF LITERATURE}

There has been extensive research conducted on people's perceptions regarding the accounting profession (Paolillo and Estes, 1982; Seamann and Crooker, 1999) as well as accountants (DeCoster and Rhode, 1971). Paolillo and Estes (1982) found that professional status and prestige were strong motivations for accounting students to consider a career in accounting, as likened to other professions such as law, medicine and technology. High demand for accounting majors was reported in the fifties to the seventies (Nelson,1995; and Previts and Merino, 1979) and its significance has also been acknowledged by several researchers (Auyeung and Sands, 2010; Marriott and Marriott, 2003; Tan and Laswad, 2006). There was also a decline of accounting graduates between 1990 and 2000 due to negative perceptions and misinformation of the profession (Arlinghaus and Cashell 2001). This started with low scores for SAT test (Inman, Wenzler, \& Wickert, 1989) which made academically bright students drop accounting for their career choice (Collins, 1987). Recently it has been claimed that the accountant's image has been changed in a positive way from, "number crunchers and business historians to business partners and trusted advisors (Siegel, 2000). Manganaris and Spathis (2012) conducted study on students perception from the beginning to end of course and found that the course turned out to be of profound interest, more rewarding, added value and high scores overtime with decreasing influence of instructor.

A set of surveys were undertaken during the epoch of the seventies to the nineties to study the accounting practitioner's requirements from the educator's point of view. Nelson (1995) found that practitioners were looking for effective knowledge, communication, interpersonal and intellectual skills among graduates rather than technical skill, which they felt could be acquired later on the job rather than in school. The course of study of various universities was focusing more on learning technical aspects of accounting rather than building a business, analytical and communication skills in their graduates (Myers, 2005). One important content of accounting education is tax and its implications. Coetzee and Oberholzer (2009) empirically tested the perception of training officers for charted accounts tax knowledge in South Africa and found that they were not satisfied with the initial practice due to lack of coordination between theoretical and practical aspects of tax education. Sin, Reid and Jones (2012) has suggested reforms in the curriculum in order to align the present accounting work to professional requirement .Amer, Baiin and Wilburn (2010) has suggested co-curricular student development activity like the career panels for providing an opportunity for students to interact with the members of Accounting Advisory Council .This will further help students to learn more about the accounting profession and the existing career opportunities to accounting majors. Research conducted on inclusion of research-led and problem-based learning task in accounting information system led to improved analytical, critical thinking and communication in higher education graduates (Carla L. Wilkin; 2014). Kutluk, F., A., et.al., (2015) studies on teaching techniques found that the students preferred the use of 
powerpoint presentations and blackboard as well quoting more of real life situations and case studies during accounting lessons .

Studies conducted to determine the definition of success among accounting school students using two dimensions namely intrinsic and extrinsic goals found that that majority of Accounting students perceived success as meeting their intrinsic goals, this includes development and networking, rather than extrinsic goals like clearing the exam (Sugahara \& Boland ,2014). These results contradict with the findings of Kawasaki et al. (2010) who stated that accounting school students were more focused on passing their CPA (Certified Public Accountants) qualification exam.

The accounting applications are of paramount significance with globalized economy and rapidly evolving technology. Boyce (1999) has reported that computer accounting cannot replace the face to face teaching .Some studies has reported negative effects of accounting software packages that they will reduce the understanding level of students for ledgers and other concepts of accounting cycle (Gujarathi and McQuade, 1998; Peters,1999). Conversely some researchers has focused on positive dimensions of such accounting packages. Marriott (2004) argues that computer simulation provides students with concrete accounting experience similar to a real business environment. In Hurt's (2007) is of the view that software helps students to learn and understand general ledger packages and other accounting tools. Effectively integrating accounting software into coursework covers requirement of both professionals and accounting organizations and enhances active learning. For instance, core competency in CPA is the ability to use IT to improve performance for customers, clients, and employers. The most effective method of enhancing IT knowledge is through education (AICPA, 2009).

Thus Literature review has revealed various aspects of accounting education and profession and this study aims to add to existing literature by presenting the stakeholders' perception and results of Need analysis for opening accounting undergraduate program in Saudi Arabia. This study aims to achieve following research objectives:

1. To assess workforce market demand and career opportunities in the area of accounting.

2. To analyze the perception of employers and other stakeholders for opening more accounting undergraduate program in Saudi Arabia

3. To analyze the perception of students with regard to opening accounting major.

\section{METHODS}

A Need analysis is essential domain in developing new curriculum (Ping Li and Zhihong Lu ,2011). An empirical study on Needs Analysis was carried out by Yan Wu, (2012), Zahrani (2014), Guzman Mancho-Barés and Enric Llurda (2013) and Hossain (2013) to investigate the industry and community demands for designing curriculum. The present study is based on 'mixed-methods research', that makes use of both qualitative and quantitative data as well as uses both positivist and intepretivist approaches through Triangulation. In addition to articulating out how a new program will support college mission and vision, it is significant to consider the trends with respect to the new developments in industry and employment opportunities which will add credibility to the conclusions (Saunders et al, 2007).

The data collection for meeting the research objective was carried out as follows:

1. Secondary data was used to assess workforce demand and career opportunities in the area of accounting. The data was collected from documents uploaded by ministry of civil service and ministry of labor website, as well as Saudi Arabian Monetary Agency 
(SAMA). Besides this newspaper, publication, reports were also referred to in data collection.

2. Primary data was collected to receive feedback from expert stakeholders for opening more undergraduate accounting program in Saudi Arabia. The author used interview technique as well as individual and group Meetings with the following stakeholder:

- Annual Meetings with Program Advisory Committee member who are representative of local industries.

- Department Council Meeting were conducted with in house faculty members.

- Feedback from the company supervisors of the field experience students were taken during the visit of academic supervisor to companies.

- Expert comments from external program reviewer on review of the degree plan.

- Interview with representative of professional association, IMA the Institute of Management Accountants that offers the prestigious Certified Management Accountant (CMA).

3. To receive feedback about the perception of accounting major from students, survey was conducted. The target respondents were students undertaking undergraduate program in college of Business in the Eastern province of Saudi Arabia.

The duration of undergraduate study program is four academic years plus one academic year for the preparatory program. The four years spent in undergraduate program are typically known as the freshman, sophomore, junior and senior. The University Preparatory Program is a requirement for entrance into the undergraduate programs. The structured questionnaire has two sections. Section A was on the demographic characteristics of respondents. The students belonging to freshman, sophomore, junior and senior I were classified as field inexperience students while senior II as filed experience students as they were all undergoing coopt training. Section B has fifteen statements assigned with likert rating scale from 1 to 5 where 1 stands for strongly disagree and 5 stands for strongly agree. The statements focused on four attribute namely objectives, learning domains (knowledge, cognitive, interpersonal and communication skills) accounting jobs and information technology in accounting education and profession.

Respondents were randomly selected in order to eliminate the sampling frame errors. In order to get true representation of the population the study has used stratified random sampling technique. The respondents were politely approached to fill in the questionnaire. The purpose of the study was explained to respondents and then agreed respondents were left alone to answer the questionnaire to avoid interference and potential bias. The responses obtained were analyzed using SPSS (Statistical Package for Social Science) software for windows.

\section{RESULTS AND DISCUSSION}

This section explores the data and discuss the results in terms of the set research objectives:

\section{Assess Workforce Demand and Career Opportunities in the Field of Accounting}

According to the data released by the ministry of civil services and ministry of labor there are more than hundreds of job titles in the field of Accounting. Graduates of accounting program will be well positioned to take advantage of various career opportunities in different organization such as banking, transportation, hospitality, telecommunication, retail, financial services, entertainment and insurance industry.

In accordance with the Ministerial Decision No. 1982 dated 6 April 2016, the Saudi Arabian Ministry of Labor issued new implementing regulations to the Labor Law. Saudi Arabia's labor market is undergoing a large-scale transformation that will enhance its economic growth even more over the coming years. Year-on-year, there have been improvements in the labor market 
within the country, both in total working population and among specific groups, such as female workers. According to General Authority for Statistic, Kingdom of Saudia Arabia CSDI (2016) following are the facts and figure of Saudi labor market.

- Total Labor Force: 13.1 million

- Saudi Labor Force: 5.7 million 43.5\% (of total labor force)

- Saudi females unemployed: 0.4 million (3.0\%)

- Saudi females employed: 0.8 million $(6.1 \%)$

- Saudi males unemployed: 0.3 million $(2.3 \%)$

- Saudi males employed: 4.2 million (32.1\%)

While Saudi Arabia has benefitted substantially from this transformation, it has also encountered many obstacles on this path. With Vision 2030, the Kingdom's plan for building a sustainable and expanding economy for the future, MLSD newly formed Ministry of Labor and Social Development is developing initiatives to improve workforce skills, encourage greater national workplace inclusion, support private sector growth, diversify the economy and increase productivity. The government has invested heavily in researching and applying the best practices to enhance the country's labor market, but is aware there remains much to be learned from the experience of other countries, international organizations, and economic experts.

\section{Analysis of feedback from expert stakeholder}

Analysis of feedback from expert stakeholder for opening undergraduate accounting program is as follows:

$>$ Program advisory committee meetings were held annually with representatives of local industry. The committee comprised of equal representatives from the industry and the academia. The main objectives behind the meetings were to identify the needs of the stakeholders, gaps in skills and knowledge among graduates and obtain inputs in revising curriculum. Feedback from the program advisory committee members reassured that the proposed undergraduate accounting degree program is relevant to the workforce needs. The proposal was welcomed by the member and they were optimistic about high enrollments as well as growth of profession. This program will provide employers with graduates who can communicate well in Arabic and English with good leadership skills and an ability to be a team player.

$>$ Department council meeting was conducted with in house faculty members who are having expertise in field of accounting and finance. Most of the members were of foreign nationality and were very positive about the proposal due to mushrooming growth of accounting grobally. They believed that accuracy is critical in the field of accounting and an error in a calculation could lead to an erroneous decision which could have serious implication in business. According to their experience most of the students were experts in spreadsheet and could manipulate data effectively but lacked in figuring out weather the information generated is reasonable and realistic. So accountants need to be grounded in critical thinking, creative problem solving and analytical thought process in the regular classrooms to have a deeper understanding of the business operations. Policies, best practice and technology are constantly changing in today's corporate world so to be in the fore front of these changes and to maintain professional competitive advantage students should also be prepared for lifelong learning.

$>$ Feedback from the company supervisors of field experience students in different industries recommended the need for opening of more accounting undergraduate program. According to them the recruitment managers usually look for graduates in the accounting program while flipping through the resumes. As fundamental are the accounting skills so are leadership, initiative, communication and IT skills .When hiring 
accounting graduates they look for candidates who demonstrate these competencies at some point in their lives. Besides this the accountants should have ability to take complex matter and simplify it into easily understood language for non-accountants. Recruiting managers look for candidates who comfortable in dealing with coworkers at different levels as well as making recommendation or proposing alternatives solutions to management. The focus on learning expectations in traditional accounting degree was on two major learning domains namely acquisition of knowledge and cognitive skills. The contemporary Accounting degree plan in addition to acquisition of knowledge and cognitive skill focuses on managerial competencies such as interpersonal, communication, team work, IT skills and ethics to comply with the national and international accreditation. IT, one of the core competences of accountants has created explosive challenges due to its dynamic nature. Business strategy and organizational restructuring revolve around IT technology. Employers increasingly use the Bachelor degree in Accounting as a minimum entry requirement for accounting jobs. IT skills, such as the ability to use an electronic spreadsheet, ERP systems like SAP are now indispensable. Employers ensure that candidates possess core IT skills before they recruit them and the present curriculum is built on these requirements.

$>$ Use of software is increasingly becoming critical to all management functions including accounting. To bring value additional to an organization, employers are looking for accounting graduates with advanced skills in information technology, analytics, management and decision making. Consequently, curriculum in the proposed accounting program has been prepared to accommodate both management and technical trends. This is in line with the mission and vision of the College of Business which will offer the accounting program along with its existing portfolio of management programs such as Business Administration and Human Resource Management and technical programs such as Information Systems.

$>$ Expert opinion from external program reviewer was carried out for the Design of the Program, Quality Assurance Measures preparing program educational objectives, students learning outcomes, and career opportunities. Though much of program structure follows the generic accounting programs across the world, however feedback and comments from major stakeholders demand incorporating unique features such as the fellowship requirements of Saudi Organization for Certified Public Accountants (SOCPA) in the area of Accounting, Auditing, Zakat and Tax, Business Law, and Islamic Jurisprudence Statistics of Program Components were also received. The draft of the undergraduate accounting program with respective contact and credit hours for both theory and practical activity was thus framed.

$>$ Interview with representative of professional association, IMA the Institute of Management Accountants has briefed about their association and growth of accounting in today's scenario. IMA is one of the largest and most respected associations, focused exclusively on advancing the management accounting profession through research, CMA (Certified Management Accountant) program, continuing education, networking and advocacy of the highest ethical business practices. It provides localized services through its four global regions: The Americas, Asia/Pacific, Europe, and Middle East/ Africa. The local chapter in the western province of Saudi Arabia held talks about current economic conditions and new regulatory affair about Governance, Risk Management and Compliance (GRC) regulators such as the Ministry of Commerce and Industry (MOCI), Capital Market Authority (CMA) and the Saudi Arabian Monetary Authority (SAMA) in monitoring compliance standards in the country.

The 2015 edition of Trends in the Supply of Accounting Graduates and the Demand for Public Accounting Recruits publication of the results of a long-standing American Institute of CPAs 
survey revealed that Universities and firms are both optimistic about the growth of the profession $97 \%$ of bachelor's programs and 70\% of master's programs and expect their enrolment to be the same or higher than the previous year. Additionally, $91 \%$ of firms expect their hiring of new accounting graduates to be higher than or the same as the previous year. Larger firms are especially optimistic about future hiring with all large firms employing over 200 CPAs forecasting the same or more new hires in every area next year. The number of accounting graduates hired by CPA firms continued to steadily increase. Master's degree hires saw the highest growth, with an 11\% increase since 2012. Bachelor's degree hires increased $5 \%$ in the same time period. Overall growth for all new hires was $7 \%$.

\section{Analysis of the perception of students about accounting major Cronbach's Alpha:}

The questionnaire was distributed to a sample of 600 respondents and the response rate was $94.17 \%$. Data collected through questionnaire was analyzed by using SPSS. The reliability of data was tested by using Cronbach's Alpha. The closer Cronbach's alpha coefficient is to1.0 the greater the internal consistency of the items in the scale. George and Maller (2005) provided the following rules of thumb: " $>.9$ - Excellent, _ $>.8$ - Good, _ $>.7$ - Acceptable, _ $>.6$ Questionable,_> .5 - Poor, and_<.5 - Unacceptable"

The reliability of data was tested by using Cronbach's Alpha. The factor was 0.959 which shows that the test conducted was highly reliable.

\section{Principal Component Analysis (PCA) :}

Principal component analysis (PCA) was carried out to study correlations among subsets of responses to bipolar pairs. The objective is to group the fifteen manifest variables into latent variables. Before conducting PCA, initial screening of data was carried out for checking validity. Different researchers have used different techniques for initial screening data. This study has used correlation matrix followed by the Barlett's test of sophisticity and the KaiserMeyer-Olkin measure of sampling adequacy (KMO) (Tabachnik and Fidell, 2001). Table 4.1 shows that most of the observations in the matrix are having $\mathrm{R}$ value more than 0.3. Similar results are confirmed by Barlett's test of sophisticity which shows p value less than 0.001 . Here the KMO factor was 0.96 . These initial screening results suggest that data is valid to carry out PCA.

For factor analysis, points were added to a factor when they had a value of 0.5 or higher. Factor scores is computed by following the method used by Harman, 1976. Table 4.2 shows that the factor analysis has computed two factors which explain about 72 percent of the total convergence of the characteristics and are set as internal perception of Accounting Degree and External perception of accounting degree. Internal perception refers to questions addressing students' own point of view while, external perception focused on questions addressing objective, domains of skills, information technology and job market. This was based on view point of Franz Brentano's Epistemology, philosophy of mind. According to Franz there are two types of human perception, external perception through the sense organs and internal internal perception, which is the awareness of mental acts present in us (Hamburg, Meiner, 1985). 
Table 4.1 Correlation matrix for manifest variables

\begin{tabular}{|c|c|c|c|c|c|c|c|c|c|c|c|c|c|c|c|}
\hline & Q1 & Q2 & Q3 & Q4 & Q5 & Q6 & Q7 & Q8 & Q9 & Q10 & Q11 & Q12 & Q13 & Q14 & Q15 \\
\hline Q1 & 1 & & & & & & & & & & & & & & \\
\hline $\mathrm{Q} 2$ & $.856^{* *}$ & 1 & & & & & & & & & & & & & \\
\hline Q3 & $.720^{* *}$ & $.784^{* *}$ & 1 & & & & & & & & & & & & \\
\hline Q4 & $.393^{* *}$ & $.433^{* *}$ & $.449^{* *}$ & 1 & & & & & & & & & & & \\
\hline Q5 & $.738^{* *}$ & $.763^{* *}$ & $.738^{* *}$ & $.541^{* *}$ & 1 & & & & & & & & & & \\
\hline Q6 & $.731^{* *}$ & $.759^{* *}$ & $.684^{* *}$ & $.432^{* *}$ & $.791^{*}$ & 1 & & & & & & & & & \\
\hline Q7 & $.599^{* *}$ & $.630^{* *}$ & $.658^{* *}$ & $.475^{* *}$ & $.685^{*}$ & $.647^{* *}$ & 1 & & & & & & & & \\
\hline Q8 & $.616^{* *}$ & $.661^{* *}$ & $.637^{* *}$ & $.482^{* *}$ & $.693^{*}$ & $.686^{* *}$ & $.693^{* *}$ & 1 & & & & & & & \\
\hline Q9 & $.760^{* *}$ & $.776^{* *}$ & $.678^{* *}$ & $.411^{* *}$ & $.762^{*}$ & $.762^{* *}$ & $.632^{* *}$ & $.667^{* *}$ & 1 & & & & & & \\
\hline Q10 & $.629^{* *}$ & $.659^{* *}$ & $.642^{* *}$ & $.524^{* *}$ & $.677^{*}$ & $.641^{* *}$ & $.649^{* *}$ & $.651^{* *}$ & $.672^{* *}$ & 1 & & & & & \\
\hline Q11 & $.708^{* *}$ & $.727^{* *}$ & $.680^{* *}$ & $.516^{* *}$ & $.727^{*}$ & $.710^{* *}$ & $.625^{* *}$ & $.654^{* *}$ & $.732^{* *}$ & $.749^{* *}$ & 1 & & & & \\
\hline Q12 & $.679^{* *}$ & $.702^{* *}$ & $.633^{* *}$ & $.547^{* *}$ & $.707^{*}$ & $.666^{* *}$ & $.620^{* *}$ & $.642^{* *}$ & $.713^{* *}$ & $.724^{* *}$ & $.811^{* *}$ & 1 & & & \\
\hline Q13 & $.478^{* *}$ & $.520^{* *}$ & $.498^{* *}$ & $.692^{* *}$ & $.552^{*}$ & $.490^{* *}$ & $.540^{* *}$ & $.550^{* *}$ & $.478^{* *}$ & $.650^{* *}$ & $.618^{* *}$ & $.650^{*}$ & 1 & & \\
\hline Q14 & $.520^{* *}$ & $.539^{* *}$ & $.501^{* *}$ & $.543^{* *}$ & $.602^{*}$ & $.525^{* *}$ & $.549^{* *}$ & $.514^{* *}$ & $.577^{* *}$ & $.572^{* *}$ & $.619^{* *}$ & $.608^{*}$ & $.653^{* *}$ & 1 & \\
\hline Q15 & $.565^{* *}$ & $.599^{* *}$ & $.513^{* *}$ & $.345^{* *}$ & $.573^{*}$ & $.542^{* *}$ & $.489^{* *}$ & $.484^{* *}$ & $.582^{* *}$ & $.476^{* *}$ & $.493^{* *}$ & $\begin{array}{r}.519^{*} \\
*\end{array}$ & $.413^{* *}$ & $.491^{*}$ & 1 \\
\hline
\end{tabular}

Table 4.3 presents descriptive statistics about the two factors for the complete sample. The lowest mean was for internal perception with score of 3.48 while the highest score was for external perception with 3.83 . 
Table 4.2 Factor Loading

\begin{tabular}{|c|c|c|}
\hline Rotated Component Matrix & Component 1 & Component 2 \\
\hline Q1 & .859 & \\
\hline Q2 & .872 & \\
\hline Q3 & .787 & \\
\hline Q5 & .782 & \\
\hline Q6 & .822 & \\
\hline Q7 & .645 & \\
\hline Q8 & .672 & \\
\hline Q9 & .604 & \\
\hline Q10 & .695 & \\
\hline Q11 & .643 & \\
\hline Q13 & .837 & \\
\hline Q15 & .640 & \\
\hline Q4 & & .844 \\
\hline Q12 & & .862 \\
\hline Q14 & & .686 \\
\hline
\end{tabular}

Extraction Method: Principal Component Analysis. Rotation Method: Varimax with Kaiser Normalization.

Table 4.3 Descriptive Statistics of Factors

\begin{tabular}{|l|l|l|l|}
\hline Factor & Rank & Mean & Standard Deviation \\
\hline External Perception & 1 & 3.8361 & 1.05584 \\
\hline Internal Perception & 2 & 3.4838 & 1.22023 \\
\hline
\end{tabular}

\section{An analysis of variance (ANOVA)}

An analysis of variance (ANOVA) was run to establish whether there was a difference between the following variable taken under study.

\section{Field inexperience student vs Field experience students: Perception Analysis}

All statistical assumptions of ANOVA were met for field inexperience and field experience students. The findings of this study have revealed some interesting observations about field inexperience and field experience students perception about undergraduate accounting program. Table 4.4 has shown that there is significant difference between the perceptions of two group of students about undergraduate accounting program for both factors of analysis i.e. internal as well as external perception. 
Table 4.4 Field Inexperience vs Field Experience Students' Perception Analysis ANOVA

\begin{tabular}{|cc|c|c|c|c|c|}
\hline & & Sum of Squares & $\mathrm{df}$ & Mean Square & $\mathrm{F}$ & Sig. \\
\hline Internal & Between Groups & 6.915 & 1 & 6.915 & 4.675 & .031 \\
Perception & Within Groups & 832.853 & 563 & 1.479 & & \\
& Total & 839.768 & 564 & & & \\
\hline External & Between Groups & 5.539 & 1 & 5.539 & 5.004 & .026 \\
Perception & Within Groups & 622.088 & 562 & 1.107 & & \\
& Total & 627.627 & 563 & & & \\
\hline
\end{tabular}

Table 4.5 reports significant mean difference between field inexperience students and field experience students about undergraduate accounting program.

Table 4.5 Field Inexperience vs Field Experience Students' Perception Analysis

\begin{tabular}{|c|c|c|c|c|c|c|c|c|}
\hline & Groups & $\mathrm{N}$ & Mean & $\begin{array}{c}\text { Std. } \\
\text { Deviation }\end{array}$ & $\begin{array}{c}\text { Std. Error } \\
\text { Mean }\end{array}$ & Minimum & Maximum & $\begin{array}{c}\text { Mean Difference } \\
\text { (significance) }\end{array}$ \\
\hline \multirow{2}{*}{$\begin{array}{l}\text { Internal } \\
\text { Perception }\end{array}$} & $\begin{array}{c}\text { Field } \\
\text { Inexperience }\end{array}$ & 530 & 3.4553 & 1.22641 & .05327 & 1 & 5 & $-0.4589 * *$ \\
\hline & Field Experience & 35 & 3.9143 & 1.04582 & .17678 & 1.33 & 5 & $(-2.162)$ \\
\hline \multirow{2}{*}{$\begin{array}{l}\text { External } \\
\text { Perception }\end{array}$} & $\begin{array}{c}\text { Field } \\
\text { Inexperience }\end{array}$ & 529 & 3.8106 & 1.07015 & .04653 & 1 & 5 & $-0.4108^{* *}$ \\
\hline & Field Experience & 35 & 4.2214 & .71570 & .12098 & 2.167 & 5 & $(-2.237)$ \\
\hline \multicolumn{9}{|c|}{$\begin{array}{l}* * * \text { the mean difference is significant at the } 0.01 \text { level. } \\
* * \text { the mean difference is significant at the } 0.05 \text { level. } \\
\text { *. the mean difference is significant at the } 0.10 \text { level. }\end{array}$} \\
\hline
\end{tabular}

It could be noticed that field experience students carry significantly more positive internal and external perception about undergraduate accounting program while field inexperience students carry less positive internal and external perception about undergraduate accounting program. The scores for internal perception by field inexperience student were 3.46 and for field experience students were 3.91, while the external perception had score of 3.81 for Field inexperience student and 4.22 for field experience students.

The field experience students had direct contact with real world accountants when performing tasks. Their positive view of the accountant program is a good indication of the healthier perspective the profession is experiencing in Saudi Arabia. This image of the accountant is not yet distorted and is shifting to one that is more positive (Siegel, 2000).

\section{Student vs Student: in depth demographic analysis}

In order to get insight into the variation of students' perception about the need for undergraduate accounting program, students demographic differences were analyzed. The demographic characteristics taken into consideration were gender, level of seniority and their major.

\section{Male vs Female students: perceptions of New Accounting Degree}

In order to analyze the difference between male and female students' perception about undergraduate accounting program ANOVA test was carried out. Findings in Table 4.6 shows that there exists significant difference between the internal and external perception of male and female students about undergraduate accounting program. Further statistics in Table 4.7 
show that male students are having significantly more positive internal and external perception as compared to female students. The mean difference between both groups for internal perception is 0.24 significant at $10 \%$ while for external perception this difference is 0.50 significant at $1 \%$.

These findings were contrary to the finding of Hammami \& Hossain (2010) where female students construct a more positive image about accountants compared to males.

Table 4.6 Difference Between Perception of Male and Female Students ANOVA

\begin{tabular}{|ll|c|c|c|c|c|}
\hline & & Sum of Squares & $\mathrm{df}$ & Mean Square & $\mathrm{F}$ & Sig. \\
\hline Internal & Between Groups & 4.736 & 1 & 4.736 & 3.162 & .076 \\
Perceptio & Within Groups & 790.930 & 528 & 1.498 & & \\
$\mathrm{n}$ & Total & 795.665 & 529 & & & \\
\hline External & Between Groups & 20.780 & 1 & 20.780 & 18.755 & .000 \\
Perceptio & Within Groups & 583.892 & 527 & 1.108 & & \\
$\mathrm{n}$ & Total & 604.672 & 528 & & & \\
\hline
\end{tabular}

Table 4.7 Factor Mean of Male and Female Students

\begin{tabular}{|c|c|c|c|c|c|}
\hline & Groups & $\mathrm{N}$ & Mean & Std. Deviation & Mean Difference (significance) \\
\hline \multirow{2}{*}{$\begin{array}{c}\text { Internal } \\
\text { Perception }\end{array}$} & Male & 101 & 3.6502 & 1.25908 & $.24069 *$ \\
\hline & Female & 429 & 3.4095 & 1.21555 & $(1.778)$ \\
\hline \multirow{2}{*}{$\begin{array}{c}\text { External } \\
\text { Perception }\end{array}$} & Male & 101 & 4.2186 & .90107 & $.50428^{* * *}$ \\
\hline & Female & 428 & 3.7144 & 1.08503 & $(4.331)$ \\
\hline
\end{tabular}

\section{BUS vs MIS major: perceptions of undergraduate accounting program}

Two majors namely Business Administration (BUS) and Management information system (MIS) were considered in this study and differential analysis was carried out on basis of these Major. Results in Table 4.8 and Table 4.9 show that there is significant difference between the perceptions of students in both majors. Business Administration major students are found to be more optimistic about the external and internal perceptions about undergraduate accounting program as compared to Management Information System students. The mean difference between the perceptions of both groups for internal perception is 0.30 which is significant at $1 \%$ and for external perception this difference is 0.24 significant at $1 \%$.

Table 4.8 Major wise Comparison of Perception

ANOVA

\begin{tabular}{|l|l|c|c|c|c|c|}
\hline \multicolumn{2}{|c|}{} & $\begin{array}{c}\text { Sum of } \\
\text { Squares }\end{array}$ & df & $\begin{array}{c}\text { Mean } \\
\text { Square }\end{array}$ & F & Sig. \\
\hline Internal & Between Groups & 19.951 & 1 & 19.951 & 13.580 & .000 \\
Perception & Within Groups & 775.714 & 528 & 1.469 & & \\
& Total & 795.665 & 529 & & & \\
\hline External & Between Groups & 7.355 & 1 & 7.355 & 6.489 & .011 \\
Perception & Within Groups & 597.317 & 527 & 1.133 & & \\
& Total & 604.672 & 528 & & & \\
\hline
\end{tabular}


Table 4.9 Factor Means of Students having Different Majors

\begin{tabular}{|c|c|c|c|c|c|}
\hline & Groups & $\mathrm{N}$ & Mean & Std. Deviation & Mean Difference (significance) \\
\hline \multirow{2}{*}{$\begin{array}{c}\text { Internal } \\
\text { Perception }\end{array}$} & BUS & 221 & 3.6848 & 1.13870 & $.39350^{* * *}$ \\
\hline & MIS & 309 & 3.2913 & 1.26190 & (3.685) \\
\hline \multirow{2}{*}{$\begin{array}{c}\text { External } \\
\text { Perception }\end{array}$} & BUS & 221 & 3.9498 & 1.03257 & $.23908^{* * *}$ \\
\hline & MIS & 308 & 3.7108 & 1.08702 & $(2.569)$ \\
\hline
\end{tabular}

The review of literature states that there is paradigm shift from not so favorable to favorable attitude towards accounting profession. The target population for the proposed Accounting program would be prospective students enrolling in the college of Business. The college of Business usually prefers to opt for two significant majors namely Business Administration and MIS in the region. Evaluating the attitude of students from Business Administration and MIS majors is an important parameter in expanding degree opportunities in accounting major. Their response will confirm non-duplication with their major extend to which the program will suffice the demands of students for successful careers.

These results are almost similar to the findings of Hammami \& Hossain (2010) where they found that Management Information System students showed least positive response for accounting major in comparison to all other majors. These results could be due to reason that Business Administration students have higher probability of getting accounting jobs in comparison to Management Information System students, which would have created biased attitude.

\section{Level of seniority: perceptions of Accounting Degree}

The study has also conducted differential analysis based on level of seniority among undergraduate students. This level is determined by the number of years spend in undergraduate studies. As mentioned earlier the levels comprises of five groups namely preparatory year, freshmen, sophomore, junior and senior. Table 4.10 and 4.11 analyzed the test of variation based on these five levels. Results show that there is significant difference between the perceptions of students from different levels. The findings show that preparatory year students are found to have significantly less positive perception regarding need of undergraduate accounting program as compared to students of all other levels. These results are consistent for both factors i.e. internal and external perception. Freshmen students were having highest positive perception about need of undergraduate accounting program as compared to all other levels. Study could not find any significant difference in internal and external perception of undergraduate accounting program between sophomore, junior and senior level students. Reason for more positive response from freshmen as compared to all other levels might be due to fact that the younger generation are ready to try out career options in the field of accounting. 
Table 4.10 Level of Seniority Based Comparison about Perceptions

ANOVA

\begin{tabular}{|l|l|c|c|c|c|c|}
\hline \multicolumn{2}{|l|}{} & Sum of Squares & df & Mean Square & F & Sig. \\
\hline $\begin{array}{l}\text { Internal } \\
\text { Perception }\end{array}$ & Between Groups & 34.332 & 4 & 8.583 & 5.955 & .000 \\
& Within Groups & 755.294 & 524 & 1.441 & & \\
& Total & 789.625 & 528 & & & \\
\hline External & Between Groups & 48.320 & 4 & 12.080 & 11.356 & .000 \\
& Within Groups & 556.351 & 523 & 1.064 & & \\
& Total & 604.672 & 527 & & & \\
\hline
\end{tabular}

Table 4.11 Factor Means of Students on different Level of Seniority

\begin{tabular}{|c|c|c|c|c|c|}
\hline \multirow{2}{*}{\multicolumn{2}{|c|}{ Comparison Level }} & \multicolumn{2}{|c|}{ Internal Perception } & \multicolumn{2}{|c|}{ External Perception } \\
\hline & & Mean Difference & Sig. & Mean Difference & Sig. \\
\hline \multirow[t]{4}{*}{ Preparatory } & Freshmen & $-1.10853^{* * *}$ & .000 & $-1.25631^{* * *}$ & .000 \\
\hline & Sophomore & -.40891 & .127 & $-.74808^{* * * *}$ & .000 \\
\hline & Junior & $-.61616^{* *}$ & .027 & $-.83207^{* * *}$ & .000 \\
\hline & Senior & $-.46777^{*}$ & .052 & $-.58412^{* * *}$ & .001 \\
\hline \multirow[t]{3}{*}{ Freshmen } & Sophomore & $.69961^{* * *}$ & .006 & $.50824^{* *}$ & .033 \\
\hline & Junior & .49237 & .225 & .42424 & .222 \\
\hline & Senior & $.64076^{* *}$ & .015 & $.67219^{* * *}$ & .001 \\
\hline \multirow[t]{2}{*}{ Sophomore } & Junior & -.20725 & .756 & -.08399 & .980 \\
\hline & Senior & -.05886 & .991 & .16396 & .568 \\
\hline Junior & Senior & .14839 & .911 & .24795 & .452 \\
\hline $\begin{array}{l}* * * \text { the mean } \\
* * \text { the mean } d \\
* \text {. the mean dif } \\
\text { * the }\end{array}$ & $\begin{array}{l}\text { fference is sig } \\
\text { erence is sign } \\
\text { rence is signi }\end{array}$ & $\begin{array}{l}\text { ant at the } 0.01 \text { leve } \\
\text { int at the } 0.05 \text { level } \\
\text { it at the } 0.10 \text { level. }\end{array}$ & & & \\
\hline
\end{tabular}

\section{CONCLUSION}

The need analysis study was timely given the recent changes in accounting globally as well as in Saudi Arabia. There is favorable perception among the stakeholders regarding opening undergraduate accounting program in Saudi Arabia. High demand was found from the male students as compared to female students. Students from different levels of seniority too had given favorable response regarding opening of undergraduate accounting program. The study got positive response when tested in four dimensions naming information technology, learning outcomes, objective and job market for accounting degree. Results also support that accounting degree will help students in getting theoretical knowledge, cognitive, communication, interpersonal skills and information technology skills which will help them in meeting the requirements in job market. Details about the student demographic factors revealed a strong impact on shaping the image of the accountant. The research sample consisted of students from only eastern province. To overcome this limitation future research could enlarge the target population as well as diversify the academic setting of the research to increase the external and internal validity of the findings. 
Shahid, H., Alexander, A., \& Abdalla, T. A. M. (2018). An Exploratory Study for Opening Accounting Undergraduate Program in Saudi Arabia: The Stakeholders' Perception \& Need Analysis. Advances in Social Sciences Research Journal, 5(4) 212-227.

\section{References}

AICPA (2009), CPA Vision: Focus on the Horizon, 2011 and Beyond, American Institute of Certified Public Accountants, New York, NY.

Amer, T. S., Bain, C. E., \& Wilburn, N. L. (2010), "Increasing student awareness of the accounting profession: Utilizing accounting career panels as a cocurricular student activity", Advances in Accounting Education: Teaching and Curriculum Innovations, Vol 11, pp 129-151.

Arlinghaus, B. P., \& Cashell, J. D. (2001), “Changing perceptions about public accounting careers”, Ohio CPA Journal, Vol 60 No 2, pp 22-27.

Aysel G. (2014), "Role of technology in accounting and e-accounting”, Procedia - Social and Behavioral Sciences, $152,852-855$.

Auyeung, P. \& Sands, J. (2010), “Factors influencing accounting students' career choice: a cross-cultural validation study", Accounting Education Vol. 6 No 1, pp 13-23.

Boyce, G. (1999), “Computer-assisted teaching and learning in accounting: pedagogy or product?", Journal of Accounting Education, Vol. 17 Nos 2/3, pp. 191-220.

Carla L.Wilkin (2014), "Enhancing the AIS curriculum: Integration of a research-led, problem-based learning task", Journal of Accounting Education, Vol 32 No 2, pp 185-199.

Coetzee, S., Oberholzer, R. (2009), "The Tax Knowledge of South African Trainee Accountants: A Survey of the Perceptions of Training Officers in Public Practice", Accounting Education, Vol 18, pp. 421-441.

Collins, S. H. (1987), “News feature-recruitment”, Journal of Accountancy, pp 52-58.

DeCoster, D. T., \& Rhode, J. G. (1971), “The accountants' stereotype - Real or imagined, deserved or unwarranted”, The Accounting Review, Vol 46 No 4, pp 651-664.

Diminik, T. and Felton, S. (2006), "Accountant stereotype in movies distributed in North America in the twentieth century", Accounting, Organization and Society, Vol. 31 No. 2, pp. 129-155.

Employment Outlook. Retrived From http://www.goinglobal.com/articles/1833/

Friedman, A. L., \& Lyne, S. R. (1997), "Activity-based techniques and the death of the beancounter", European Accounting Review, Vol 6 No 1, pp 19-44.

Friedman, A. L., \& Lyne, S. R. (2001), “The beancounter stereotype: Towards a general model of stereotype generation", Critical Perspectives on Accounting, Vol 12 No 4, pp 423-451.

General Authority for statistics kingdom of Saudi Arabia. Retrived from https://www.stats.gov.sa/en/815-0

Ghasemi, M., Shafeiepour, V., Aslani, M., Barvayeh, E., (2011), “The impact of Information Technology (IT) on modern accounting systems", Social and Behavioral Sciences, Vol 28, pp. 112 - 116

Gujarathi, M.R. and McQuade, R.J. (1998), "Problems and considerations in implementing technology-based solutions to address changes in accounting curricula", Advances in Accounting Education, Vol. 1 No. 1, pp. 1-23.

Guzman Mancho-Barés, Enric Llurda (2013), "Internationalization of Business English communication at university: A three-fold needs analysis", Ibérica, Vol 26, pp 151-170.

Hamburg: Meiner, (1985), "Preprint version of a review of Franz Brentano's Deskriptive Psychologie”, Philosophy and Phenomenological Research, vol 45, pp 627-44.

Hammami, H., Hossain, M. (2010), "Perceptions of the accountant held by business students and business professionals in an emerging country: The case of Qatar", Education, Business and Society: Contemporary Middle Eastern Issues, Vol. 3 No 1, pp.48-62.

Harman, H. (1976), Modern Factor Analysis, 3rd ed., Chicago University Press, Chicago, IL

Hoffjan, A. (2004), "The Image of the Accountant in a German Context", Accounting and the Public Interest, Vol. 4 No. 1, pp. 62-89.

Hossain. J. (2013), “ESP Needs Analysis for Engineering Students: A Learner Centered Approach”, Journal of PU, Part: B, Presidency University, Vol.2 No.2, pp 16-26

Hunt, S. C., A. A. Falgiani, et al. (2004), "The nature and origins of students' perceptions of accountants", Journal of Education for Business, Vol 79 No3, pp 142-148.

Hurt, B. (2007), "Teaching what matters: a new conception of accounting education", Journal of Education for Business, Vol. 82 No. 5, pp. 295-299. 
Inman, B. C., A. Wenzler, et al. (1989), "Square pegs in round holes: Are accounting students well-suited to today's accounting profession?", Issues in Accounting Education, vol 4 No 1, pp 29-47.

Kawasaki, T., Satoh, N., Kurokawa, Y., Suzuki, Y., Kobayashi, Y., Wakita, R.(2010), “The Educational Role of Accounting Schools for Certified Public Accountants (Kouninkaikeishi ikusei ni okeru kaikei daigakuin no yakuwari)", Corporate Accounting (Kigyo kaikei), Vol 62 No 10 pp. 39-68.

Kutluk, F., A., Adnan Donmez, A., Gülmez, M., (2015), “Opinions of University Students about Teaching Techniques in Accounting Lessons", Procedia - Social and Behavioral Sciences, Vol 191, pp 1682-1689

Manganaris, P., Spathis, C. (2012), “Greek Students' Perceptions of an Introductory Accounting Course and the Accounting Profession, in Dorothy Feldmann, Timothy J. Rupert (ed.) Advances in Accounting Education: Teaching and Curriculum Innovations (Advances in Accounting Education, Volume 13) Emerald Group Publishing Limited, pp.59- 85

Marriott, D.N. (2004), "Using computerized business simulations and spreadsheet models in accounting education: a case study", Accounting Education: An International Journal, Vol. 13, No 1, pp. 55-70.

Marriott, P., \& Marriott, N. (2003), "Are we turning them on? A longitudinal study of undergraduate accounting students' attitudes towards accounting as a profession”, Accounting Education, Vol 12 No 2, pp 113-133.

Myers, R.(2005),“Accounting education changes course”, Journal of Accountancy,Vol.200 No.4, pp.108-110.

Nelson,I.T.(1995),"What's new about accounting education change? An historical perspective on the change movement", Accounting Horizons, Vol. 9 No. 4, pp. 62-76.

Paolillo, J.G.P. and Estes, R.W. (1982), "An empirical analysis of career choice factors among accountants, attorneys, engineers, and physicians”, The Accounting Review, Vol. 57 No. 4, pp. 785-793.

Peters, J.M. (1999), “A study focusing on the use of Peachtree software in introductory accounting: performance differences", working paper, College of DuPage, Glen Ellyn, IL.

Ping Li and Zhihong Lu .(2011), "Learners' Needs Analysis of a New Optional College English Course Interpreting for Non-English Majors”, Theory and Practice in Language Studies, Vol. 1, No. 9, pp. 1091-1102.

Previts, G. J., \& Merino, B. D. (1979), “A history of accounting in America: An historical interpretation of the cultural significance of accounting", New York, NY: Ronald Press.

Saemann, G.P. and Crooker, K.J.(1999), "Student perceptions of the profession and its effect on decisions to major in accounting", Journal of Accounting Education, Vol 17 No 1, pp. 1-22.

Saudi Arabian companies face fresh challenge from new accounting standards. October 16, 2016. Retrieved from https://www.thenational.ae/business/saudi-arabian-companies-face-fresh-challenge-from-new-accountingstandards-1.156092.

Saunders, M., Lewis, P., \& Thornhill, A. (2007), “Research Methods for Business Students”, (4th ed.). London: Financial Times Prentice Hall.

Siegel, G. (2000), “The image of corporate accountants”, Strategic Finance, Vol. 8 No. 2, pp. 71-76.

Sin, S., Reid, A. \& Jones, A. (2012), “An exploration of students' conceptions of accounting work”, Accounting Education, Vol 21 No 4, pp 323-340.

Sugahara, S. \& Boland, G. (2014), "How Accounting Students Define Success, And The Factors Affecting Their Success And Failure, While Studying In The Accounting Schools Of Japan”, Procedia - Social and Behavioral Sciences, Vol 141, pp $64-69$.

Tabachnik, B. \& Fidell, L. (2001), “Using Multivariate Statistics”, 4thed. ,Alyn \& Bacon, Boston, MA

Tan, L.M. and Laswad, F. (2006), "Students' beliefs, attitudes, and intentions to major in accounting”, Accounting Education: An International Journal, Vol. 15 No. 2, pp. 167-187.

White, G. and White, M. (2006), “Perceptions of accountants: what are they after Enron and Worldcom?”, Journal of College Teaching and Learning, Vol. 3 No. 11, pp. 71-76.

Yan Wu. (2012), "An Empirical Study on Needs Analysis of College Business English Course”, International Education Studies, Vol. 5, No. 2, pp 216-221.

Zahrani, M. Y. (2014), “A Needs Analysis of Reading Skills For Foundation Year in ELI”, International journal of Science Commerce and Humanities, Vol 2 No 4. 